\title{
7. VOLCANICLASTIC SEDIMENTS OF THE NORTH AOBA BASIN: DEPOSITIONAL PROCESSES AND GEOLOGIC HISTORY ${ }^{1}$
}

\author{
Margaret R. Goud Collins ${ }^{2}$
}

\begin{abstract}
The tectonic and volcanological history of the central New Hebrides Island Arc since late Miocene time is reflected in the sedimentology of two Ocean Drilling Program (ODP) drill sites in the intra-arc North Aoba Basin. Sites 832 and 833 are located on the floor and the eastern margin, respectively, of a summit basin with water depth of over $3000 \mathrm{~m}$. At each site, drilling reached depths greater than 1000 meters below seafloor (mbsf), and the cores represent the first opportunity to examine a thick section of intra-arc basin sediments.

The cores are notable for thick sequences of volcanogenic sediments. Volcanism produced layers up to $42 \mathrm{~m}$ thick of unadulterated volcanic material, in sequences that grade upward from lapilli, to thick layers of volcanic sand, to fine ash and clay. The rapid erosion that accompanied volcanism and tectonic uplift of islands produced thick layers of breccia and conglomerate, featuring a wide variety of clasts of terrigenous and shallow-water origin, which serve as the basal layers of fining upward sequences.

The sediments reflect four periods of island building. Volcaniclastic debris flows and coarse-grained turbidites, overlain by calcareous, fine-grained turbidites and hemipelagic sediments, were recovered from the deepest $240 \mathrm{~m}$ of Site 832 . These sediments resulted from island building that I interpret as volcanism and uplift on Maewo Island in the late Miocene, with contributions of eroded sediment from Espiritu Santo Island. During the Pliocene, continuing erosion on Maewo Island and volcanism in the area contributed calcareous and volcanogenic debris to the hemipelagics, silty turbidites, and tephra collecting at both sites. Uplift and extension during the middle Pliocene are suggested by normal faulting in the sediments, and by an unconformity at Site 832. From latest Pliocene to early Pleistocene times, renewed uplift and volcanism on surrounding islands revived debris-flow deposition. Late Pleistocene sedimentation was dominated by volcanic ashflows as Central Chain volcanoes built depositional aprons. Tephra falls interbedded with hemipelagic sediments have dominated sedimentation in recent times.
\end{abstract}

\section{INTRODUCTION}

Sites 832 and 833 are located on the floor of the intra-arc North Aoba Basin, in water depths of 3089 and 2629 m, respectively (Fig. 1). The volcaniclastic sediments recovered from the two drill holes, each of which reached sub-seafloor depths of more than $1000 \mathrm{~m}$, offer a sedimentological record of the tectonic and volcanic history of the central New Hebrides Island Arc since the Miocene. The North Aoba Basin holes are less than $100 \mathrm{~km}$ from five volcanic islands, and rocks exposed on the islands reveal three distinct periods of volcanism and uplift (Table 1). The cores, examined in the light of the geology of the surrounding islands, provide a glimpse of the scale and duration of the seafloor sedimentation processes associated with these three known tectonic and volcanic episodes. Conversely, because the basin's sedimentation is controlled by the activity of the surrounding islands, the cores offer the most continuous available record of the islands' history (Carey and Sigurdsson, 1984).

The proximity of Sites 832 and 833 to active volcanic islands and the number of sediment sources make this the best available record of the arc-basin sedimentary processes resulting from volcanic and tectonic activity. The cores contain interbedded debris flows, turbidites, ashfall deposits, and hemipelagic sediments (Fig. 2) comparable to the sedimentary record found in drilling on the margins of backarc basins (Klein, 1985; Carey and Sigurdsson, 1984).

\section{SITE SETTING}

The Aoba basins lie within the New Hebrides Island Arc, and form an isolated deep water area within the arc's summit platform (Fig. 1).

\footnotetext{
${ }^{\prime}$ Greene, H.G., Collot, J.-Y., Stokking, L.B., et al., 1994, Proc. ODP, Sci, Results. 134: College Station, TX (Ocean Drilling Program).

2 Coastal Research Center. Woods Hole Oceanographic Institution, Woods Hole, MA 02543. U.S.A. (Present address: Office of the Chief Scientist, National Oceanic and Atmospheric Administration, Department of Commerce, Washington. D.C. 20230.U.S.A.)
}

West of the New Hebrides Islands, the Australia-India Plate is being subducted to the east beneath the Pacific Plate at the New Hebrides Trench; the North Fiji Basin lies east of the arc. The Aoba basins are opposite the d'Entrecasteaux Zone, an aseismic ridge and a parallel seamount chain on the Australia-India Plate, which are being subducted at the New Hebrides Trench (Daniel, 1978). The basins are separated from the d'Entrecasteaux Zone by the Espiritu Santo and Malakula islands, and are divided into northern and southern segments by Aoba Island, an active island-arc volcano (Fig. 1).

The North Aoba Basin is surrounded by five volcanic islands, which were built by three episodes of volcanism and tectonism that created the New Hebrides Island Arc. The volcanic islands of the arc are grouped into the Western Belt, the Eastern Belt and the presently active Central Chain (Fig. 1, Table 1; Carney and Macfarlane, 1982; Macfarlane et al., 1988). The island-arc history is described briefly here.

The oldest rocks in the Western Belt, which comprises Espiritu Santo and Malakula islands, are volcaniclastic turbidites and breccias derived from a partly emergent volcanic arc active in the late Oligocene/early Miocene (Mitchell and Warden, 1971; Carney et al., 1985). The early Miocene sediments are intruded by dikes and sills that bear phenocrysts of the same minerals found in the adjacent volcaniclastic sediments (Mitchell and Warden, 1971). Volcanism continued through the middle Miocene, after which subsidence and faulting created a north-trending graben that was filled with at least $4000 \mathrm{~m}$ of volcanogenic graywackes and pelagic sediments that are now exposed on Espiritu Santo and Malakula (Fig. 3; Carney et al., 1985). Uplift and erosion after about $11 \mathrm{Ma}$ was followed by resubmergence in the late Miocene, so that the middle Miocene pelagic sediments are overlain unconformably by late Miocene/early Pliocene ( $8.5-5 \mathrm{Ma}$ ) hemipelagic and pelagic mudstones and turbidites (Fig. 3; Mitchell and Warden, 1971; Carney and Macfarlane, 1982). By the late Pliocene, the Western Belt had been uplifted, collecting an upper Pliocene-lower Pleistocene terrigenous, volcaniclastic sequence and a cap of PleistoceneHolocene age reef limestone that documents hundreds of meters of uplift during the late Quaternary (Taylor, 1992). 

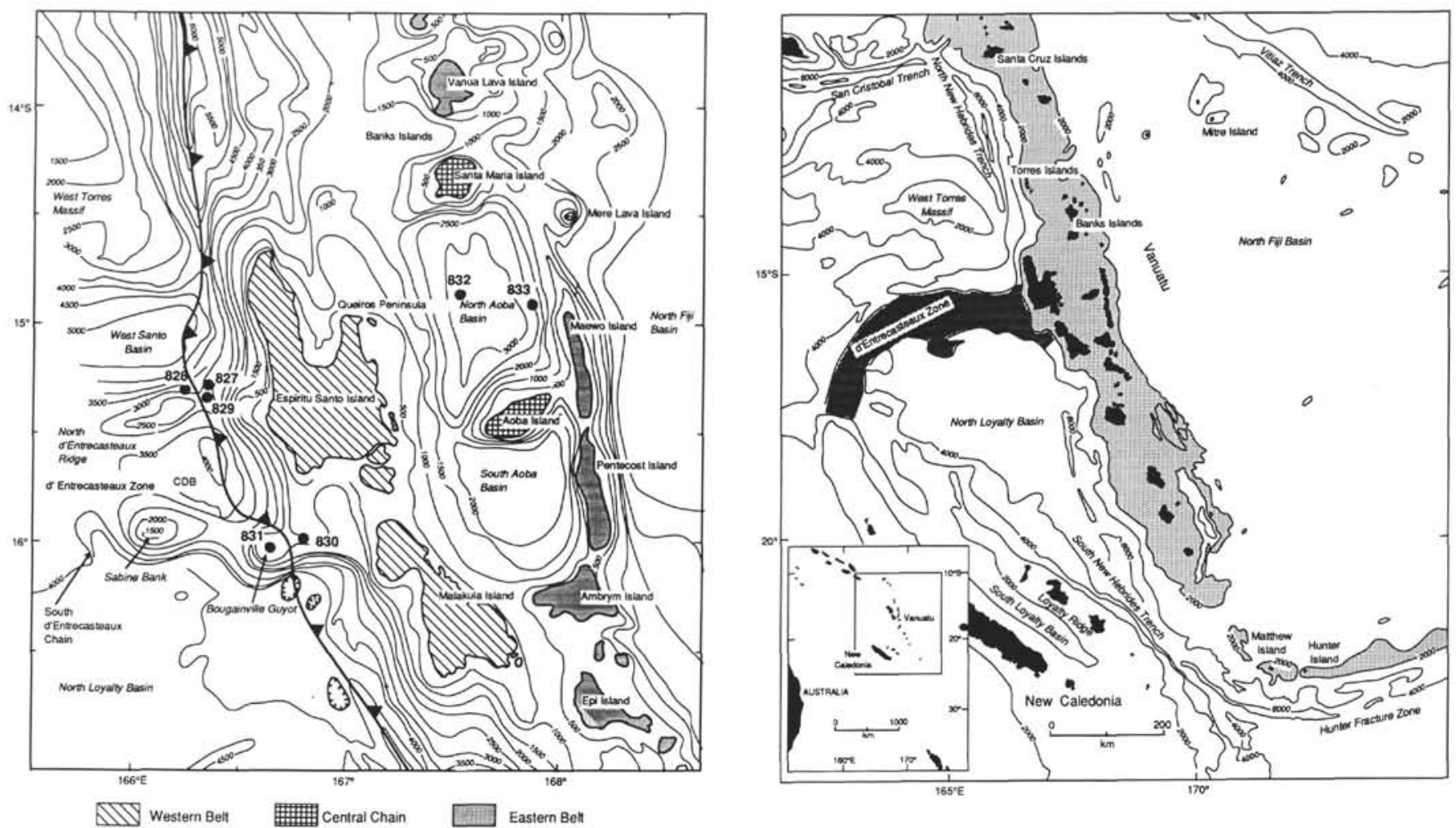

Figure 1. A. Bathymetric map of the intra-arc basins of the New Hebrides Island Arc, showing positions of Sites $827-833$. B. Regional framework.

Table 1. Islands surrounding the North Aoba Basin: distance to drill sites and age of exposed volcanic rocks.

\begin{tabular}{|c|c|c|c|c|}
\hline Island & $\begin{array}{l}\text { New Hebrides Arc } \\
\text { geological class }\end{array}$ & $\begin{array}{l}\text { Age of exposed } \\
\text { volcanic rocks }\end{array}$ & $\begin{array}{l}\text { Minimum } \\
\text { distance to } \\
\text { Site } 832 \\
(\mathrm{~km})\end{array}$ & $\begin{array}{c}\text { Minimum } \\
\text { distance to } \\
\text { Site } 833 \\
(\mathrm{~km})\end{array}$ \\
\hline $\begin{array}{l}\text { Espiritu Santo } \\
\text { (Queiros Peninsula) }\end{array}$ & Westem Belt & $\begin{array}{l}\text { late Oligocene- } \\
\text { middle Miocene }\end{array}$ & 55 & 86 \\
\hline Santa Maria & Central Chain & latest Pliocene-present & 50 & 70 \\
\hline Mere Lava & Central Chain & late Pleistocene-Holocene & 69 & 45 \\
\hline Maewo & Eastern Belt & late Miocene-early Pliocene & 56 & 20 \\
\hline Aoba & Central Chain & late Pleistocene-present & 60 & 45 \\
\hline
\end{tabular}

* From Camey and Macfarlane (1982).

The Eastern Belt, which includes Maewo and Pentecost islands, displays arc-derived volcaniclastic bathyal sediment as old as the early to middle Miocene (14-8 Ma; Carney et al., 1985). In contrast to the Western Belt, which was subsiding in the late Miocene, the Eastern Belt was being uplifted. Foraminiferal mudstones dated at 7-4 Ma indicate when the Eastern Belt rose above the Carbonate Compensation Depth (CCD); these mudstones are overlain by and interbedded with a series of pillow lavas (Fig. 3; Mallick, 1973; Carney and Macfarlane, 1982). Volcanism ended between 3 and $4 \mathrm{Ma}$ (Carney et al., 1985), and the volcanic rocks were covered by pelagic sediments. The Eastern Belt was uplifted and tilted in late Pliocene through early Pleistocene times, collecting reef-derived carbonate sediment, The youngest Eastern Belt outcrops are Pleistocene-age, off-reef limestone and, like the Western Belt, a cap of reef limestone that shows hundreds of meters of Quaternary uplift (Carney and Macfarlane, 1982; Taylor, 1992).

Active volcanism in the New Hebrides Island Arc is presently confined to the Central Chain, of which Aoba, Santa Maria, and Mere Lava islands are part. The southern islands (Tanna and Erromango) are oldest, with outcrops dating back as far as $2.4 \mathrm{Ma}$. On the Central Chain islands surrounding the North Aoba Basin, the oldest exposed volcanic rocks area are 0.4-0.7 Ma (except one remnant volcano on
Santa Maria dated at $1.8 \mathrm{Ma}$ ), and they display no raised terraces or other signs of uplift (Carney and Macfarlane, 1982).

\section{METHODS}

For this study, a detailed description and interpretation of the emplacement process for every sediment layer of every core was made, using reexaminations of the core photographs, shipboard descriptions, and selected smear slides. The characteristics and thicknesses of each sedimentary layer, defined by changes in lithology and appearance of bedding planes, were entered into a database so that variations with time and depth could be compared. Layers were differentiated by grain size, lithology, and appearance of bedding planes. The maximum thickness of a single layer was one core-length, or $9.5 \mathrm{~m}$.

The descriptions presented in this paper draw from and synthesize, but also expand upon and quantify, those generated aboard the JOIDES Resolution during Leg 134 (Collot, Greene, Stokking, et al., 1992). Emphasis is placed on the processes that operated in depositing each unit, and lithologic information is offered only insofar as necessary to explain those conclusions. Complete descriptions of the cores and their lithologies can be found in the Leg 134 Initial Reports (Collot, Greene, Stokking, et al., 1992).

\section{Classification Scheme}

Sedimentary sequences recovered from the North Aoba Basin are similar to sequences drilled in backarc basins around the western Pacific (Klein, 1985; Carey and Sigurdsson, 1984), in that they contain debris-flow deposits, turbidites, pyroclastics, hemipelagic silts and clays, biogenic pelagic carbonates, and resedimented hemipelagic sediments (Klein and Lee, 1984). The proportions of each sequence in this small confined basin differ from the proportions observed in the relatively open environment of the backarc basins, where pelagic sediments often occur in greater volume. However, the processes are generally the same, and all will be referred to as arc basins in the 


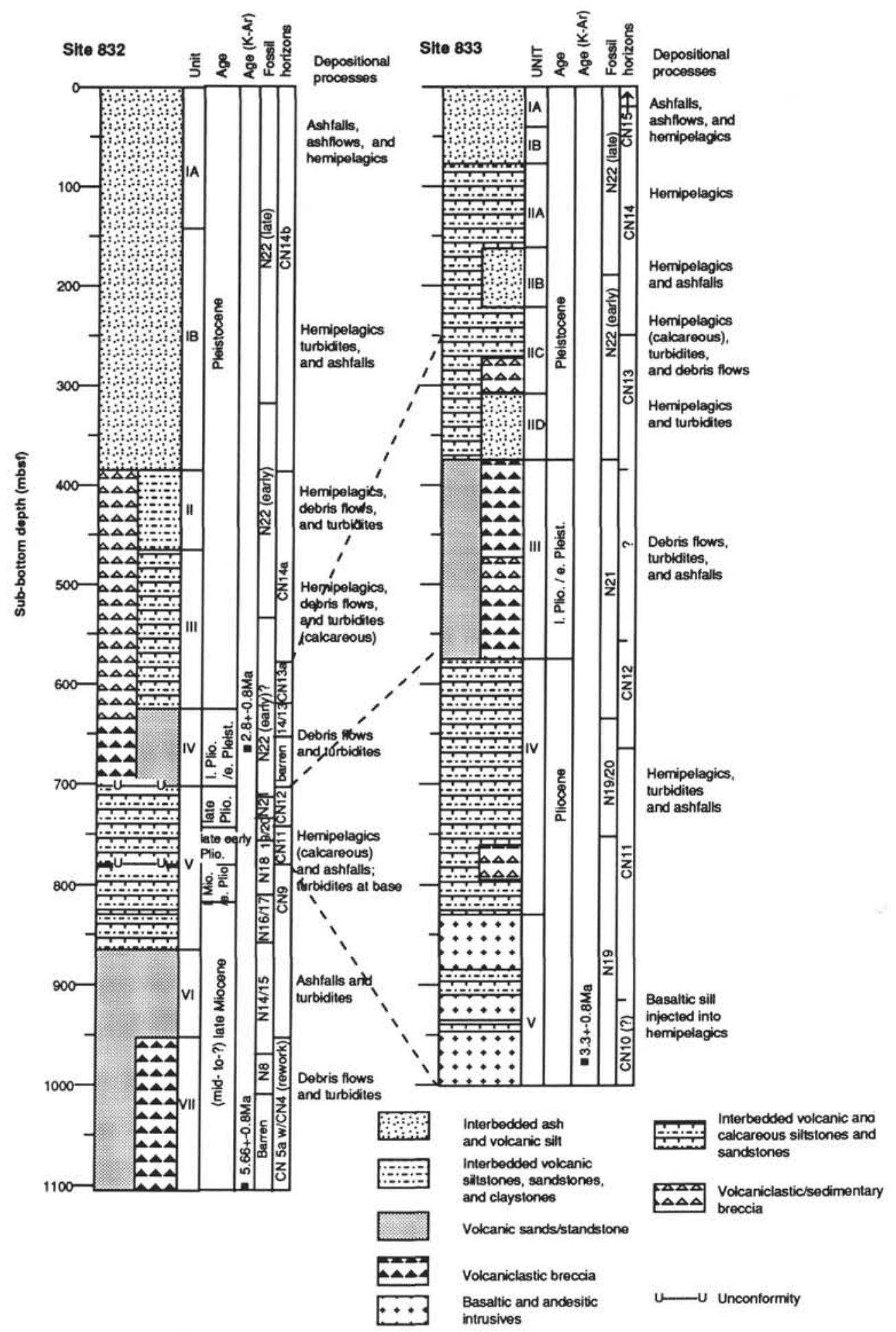

Figure 2. Composite stratigraphic columns for Sites 832 and 833. K-Ar ages from Rex (this volume). Planktonic foraminiferal ( $\mathrm{N}$-series) and calcareous nannofossil ( $\mathrm{CN}$-series) fossil horizons from Staerker (this volume), Perembo (this volume), and Shipboard Scientific Party (1992a, 1992b).

discussion that follows. The sedimentary characteristics, the dynamic processes responsible, and the occurrence in the study area for each sequence are described briefly below.

In these arc-dominated environments, debris-flow deposits are products of the gravity-driven transport of material eroded subaerially from island-arc systems (Klein, 1985). When a volcanic island is active or being uplifted, the sediment accumulates rapidly on submarine shelves and slopes until the slope becomes unstable, and gravity carries the sediments into the basin (Klein, 1985). Debris flows are sediment gravity flows that travel downslope as grain supported, laminar flows, that is, without size sorting. Debris-flow deposits can be recognized by their poorly sorted character, scoured beds, and lack 

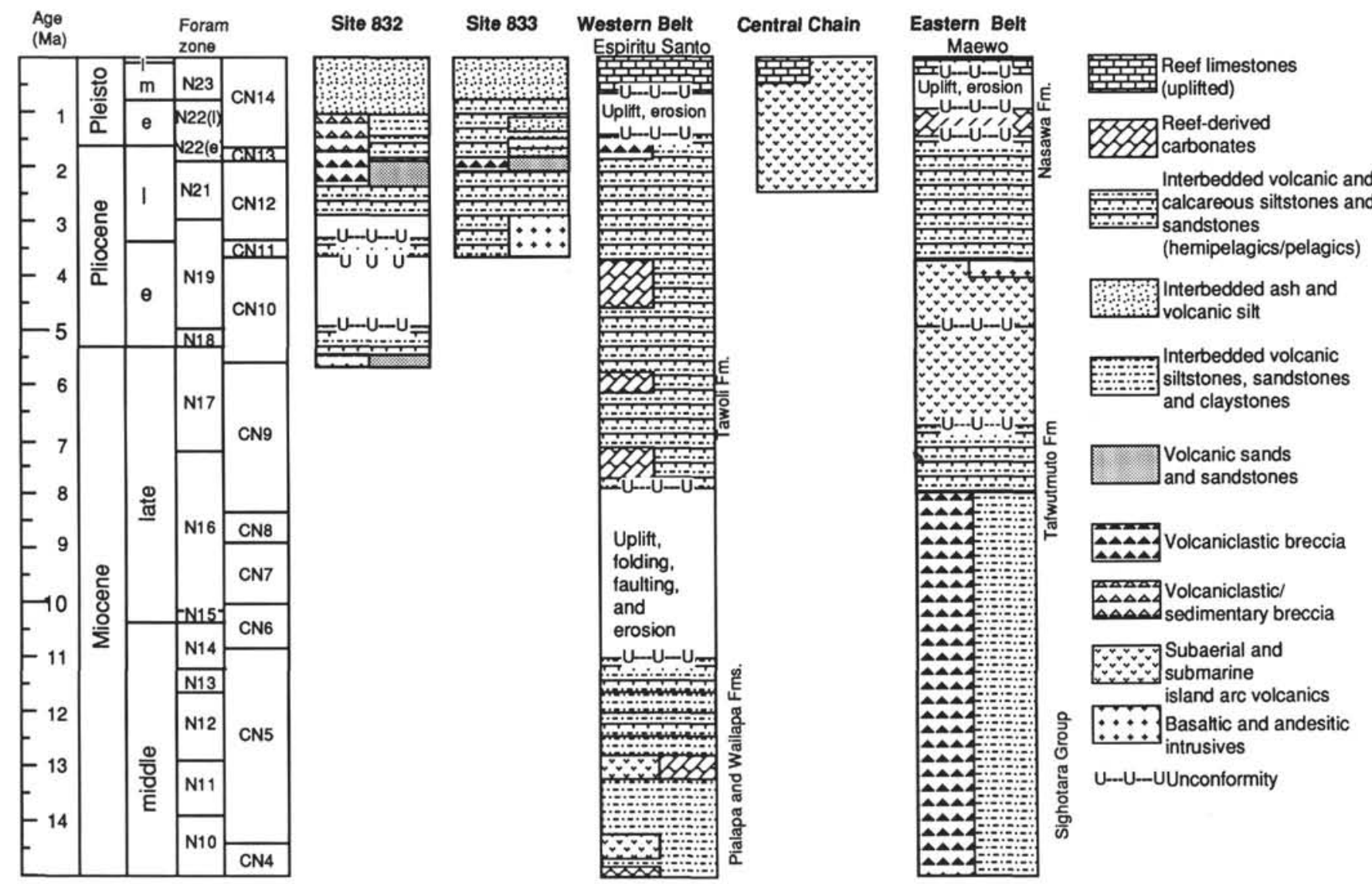

Figure 3. Geologic correlations of lithostratigraphic units from North Aoba Basin drill sites and surrounding islands, showing island geology only since the middle Miocene. Island geology after Carney and Macfarlane (1982) and Macfarlane et al. (1988). Biostratigraphic chronology from Berggren, 1985.

of sedimentary structures (Middleton and Hampton, 1973), although subaqueous volcanism could lead to similar deposits (Fisher, 1984; Mitchell and Reading, 1986). Most sedimentary breccias and conglomerates in arc basins are debris-flow deposits (Klein, 1985).

Debris flows contrast with turbidity currents, in which grains are supported by turbulent fluid that sorts the grains by density as the gravity flow moves downslope (Middleton and Hampton, 1973). Like a debris flow, a turbidity current begins when sediment accumulates to a point of instability on a submarine slope; the flow may be transformed from laminar to turbulent flow by the incorporation of seawater as it progresses (Fisher, 1984). The fining-upward sedimentary sequences that result from these turbulent grain flows are called turbidites.

Turbidites in the North Aoba Basin are of two types. Thick, coarsegrained turbidites are frequently interbedded with breccias and conglomerates (e.g., Units II and III at Site 832 and Unit III at Site 833). The rounded cobbles of sedimentary and volcanic rocks found in these sequences indicate a subaerial source, probably eroded rapidly because of tectonic uplift or volcanism. Scattered clasts of shallow-water carbonates indicate that sediment mixing occurred at shelf depths before some of the sequences of sediments were transported down slope. Neither seismic coverage nor sampling density was sufficient to determine whether the debris flows and turbidites recovered from the North Aoba Basin are part of large-scale submarine fan depositional systems, which also can result from the long-term erosion of uplifted islands (Klein, 1985). In contrast, silty basinal turbidites are often interbedded with hemipelagic sediments in the North Aoba Basin. The turbidites have thicknesses on the order of centimeters to tens of centimeters, and a pelagic biogenic sediment component of $15 \%-40 \%$ by volume, indicating a continuing terrigenous sediment supply that mingles with biogenic sediments before downslope transport.
The only unambiguously pyroclastic sediment recovered from the North Aoba Basin was ash. Even in backarc basins, most deep-sea tephra layers are $<10 \mathrm{~cm}$ thick, and ash distribution depends on wind and current patterns in the region of eruption (Fisher and Schmincke, 1984). However, in the immediate vicinity of volcanic arcs, volcanic aprons may include ash layers with thicknesses on the order of meters (e.g., Kroenke, Scott, et al., 1980). These thick ash layers may result from turbulent cloud surges, generated when hot pyroclastic flows enter the sea, or from subaqueous turbidity currents generated by ashflows that are penecontemporaneous with an eruption. (Fisher, 1984). In the North Aoba Basin, turbulent pyroclastic flows have resulted in sequences of crystal-rich or glass-rich sediments, with thicknesses from a few centimeters to tens of meters, that fine upward from basalt lapilli or sand to vitric clays.

In arc basins, hemipelagic sedimentation results from the erosion and transport of silt- and clay-sized sediment from sources on land, combined with biogenic material produced in the surface ocean. Where terrigenous input is minor, pelagic carbonate sediments dominate the sediments, as long as the seafloor is shallower than the CCD. The relative proportions of terrigenous and biogenic material in hemipelagic and pelagic sediments reflect erosion rates, volcanic activity, current patterns, and surface productivity. Hemipelagic sediments are often bioturbated, showing trace fossils and few laminations or sediment structures, although in an arc environment otherwise featureless hemipelagic and pelagic sediment layers may be broken by dark tephra layers, and multiple terrigenous sources can lead to interbed variability. In the North Aoba Basin, variable hemipelagic sediments dominate long sections of the cores (Fig. 2). Resedimented hemipelagic and pelagic sediments show signs of post-depositional downslope transport (e.g., slumps, folds), suggesting slope deposition. 
A

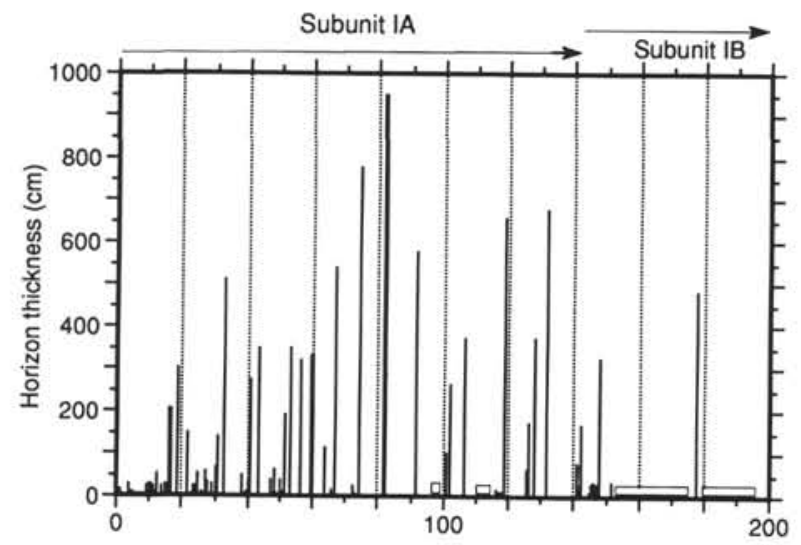

B

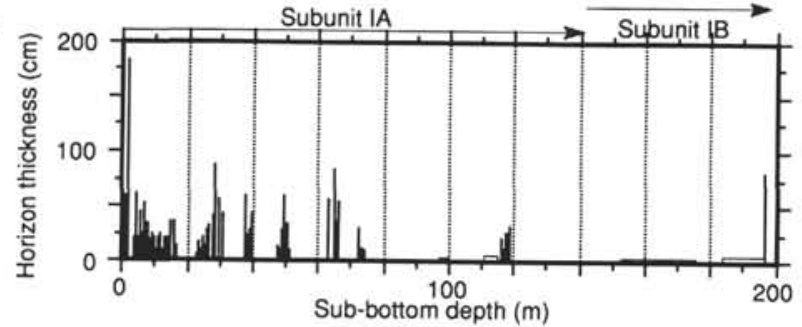

Figure 4. Depth vs, thickness relationships for sediment horizons, Hole 832A. A. Ash horizons. B. Hemipelagic horizons. Intervals of nonrecovery $>4 \mathrm{~m}$ are indicated by boxes on the $x$-axis. Plotted depth indicates the top of the layer.

\section{Site 832 Sedimentary Record}

The lithostratigraphic units assigned to the sediments recovered from Site 832, numbered I to VII, generally reflect the depositional processes that emplaced them (Fig. 2). The uppermost, Unit IA, extends to a depth of 142 meters below seafloor (mbsf), and was recovered only in Hole $832 \mathrm{~A}$, using advanced hydraulic piston coring (APC). The unit is composed primarily of vitric ash, with thin intervening layers of volcanogenic hemipelagic sediment (Fig. 4). In the upper $30 \mathrm{~m}$, the ash horizons are primarily tephra fall deposits, interbedded with hemipelagic sediments. Below $30 \mathrm{~m}$, the biogenic component of the hemipelagic beds declines and ash layers thicken: as plotted in Figure 4, ash layers show thicknesses of as much as a full core length, $9.5 \mathrm{~m}$. Some fining-upward cycles that represent a single ashfall or ashflow event are composed of two to seven consecutive layers, and range in thickness from about $20 \mathrm{~cm}$ to as much as $42 \mathrm{~m}$ (Fig. 5). The thick, fining upward sequences result from ash turbidity currents and indicate the frequency of major volcanic eruptions.

The thickest flow deposit extends from 74.3 to $116.2 \mathrm{mbsf}$. The basal interval is an 18-cm-thick gravel conglomerate containing pumice and fragments of coral, indicating a source at shelf depths. Above a 5.8-m interval of no recovery, the conglomerate is overlain by about $19 \mathrm{~m}$ of coarse-to-fine, soupy, vitric volcanic ash. Above this layer, the water content decreases as the clay content and degree of lithification increase in a 17.25-m-thick interval of fining upward, massive, silty clay, interpreted as altered fine ash, that extends from about $91.5 \mathrm{mbsf}$ to the top of the deposit. Several slumped and microfaulted veins of sandy, black vitric ash occur in the upper half of the clay bed. The two thick, disparate layers can be explained by a plinian eruption, to generate the coarse ash, contemporaneous with an ignimbrite fine-mode ash eruption (Huang, 1980; Sparks and Walker, 1977). However, the ash composition suggests a more complicated history. In Core 134-832A$12 \mathrm{H}(91.5-101.0 \mathrm{mbsf})$, the ash occurs in two varieties, one with an association of plagioclase and pyroxene, the other with pyroxene and magnetite. In the next core (134-832A-13H), the glasses are bimodal, one variety appearing fresh and pale brown, the other black and de-

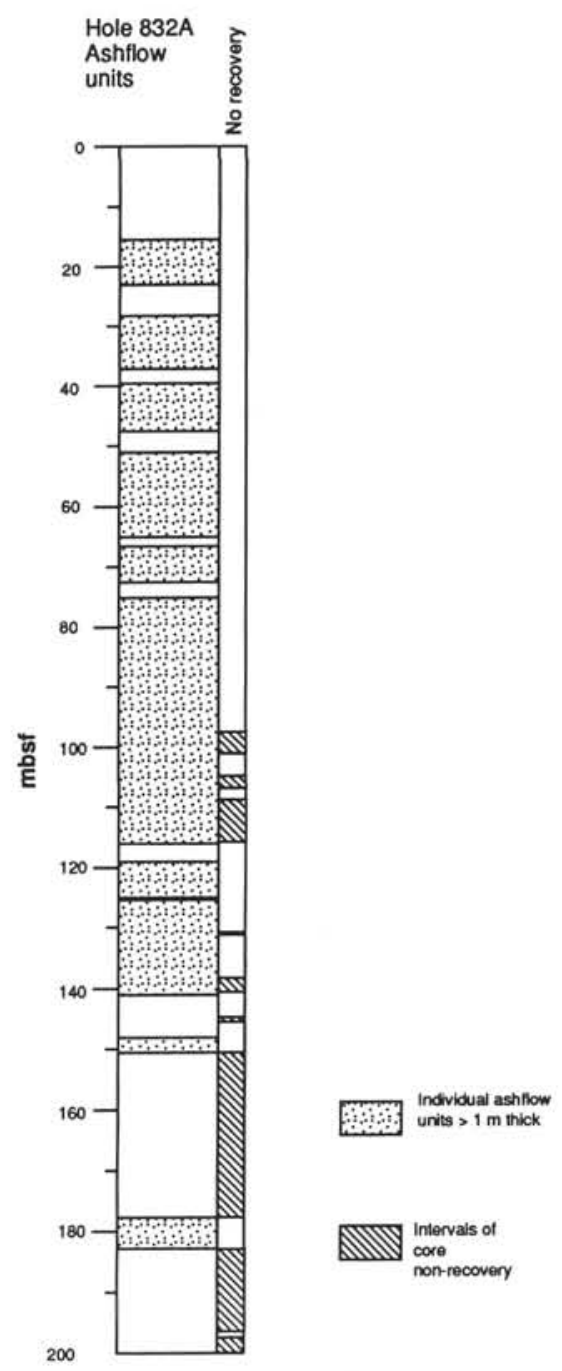

Figure 5. Subunit IA of Hole 832A, showing the sediment column divided into single ashflow events. Blank areas in column represent intervals of hemipelagic/tephra fall sedimentation.

vitrified (Shipboard Scientific Party, 1992a). These, along with the corals and pumice in the basal conglomerate, suggest that freshly erupted ash mixed in a shelf environment with products of an earlier eruption. The combined deposits were transported downslope in a massive turbidity current.

Subunit IB extends from 142 to 385 mbsf, and fine-grained ash layers continue, interbedded with increasingly dominant hemipelagic sediments in the upper $60 \mathrm{~m}$. At approximately $200 \mathrm{mbsf}$, the ash gives way to interbedded hemipelagic sediments and volcaniclastic turbidites, most with bed thicknesses on the order of tens of centimeters (Figs. 5 and 6). Below 270 mbsf, the rocks are well lithified. The beds are heterogeneous in composition, grain size, degree of bioturbation, occurrence of trace fossils, and presence of sediment structures. Most of the intervals of hemipelagic sediments are composed primarily of silt-sized volcanogenic mineral grains and clays. The biogenic calcareous component ranges from $10 \%-40 \%$ by volume, although three layers of limestone and very fine-grained chalk, 8,23 , and $140 \mathrm{~cm}$ thick, occur between 289 and 320 mbsf. Turbidites also vary in character: some are coarse volcaniclastic sand grading upward to silt, displaying no structure other than fining-upward sequences. However, near the base of Subunit IB, there is a 3.9-m-thick sequence of silty, laminated turbidites that show wavy and contorted laminations, truncated beds, load casts, and other examples of flow-generated, wet-sediment deformation (Fig. 7). 
A

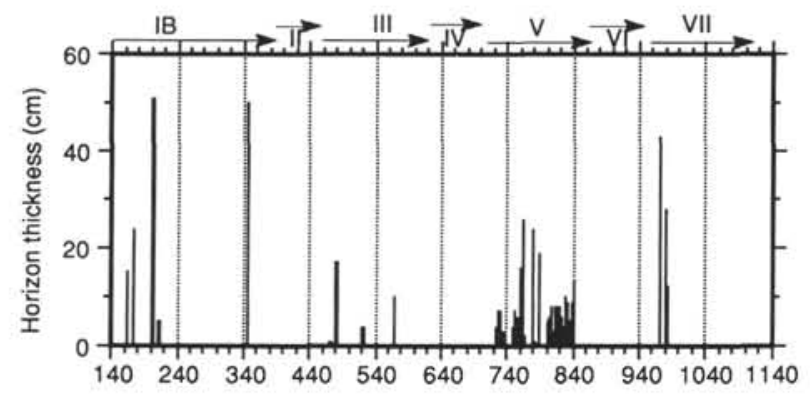

B

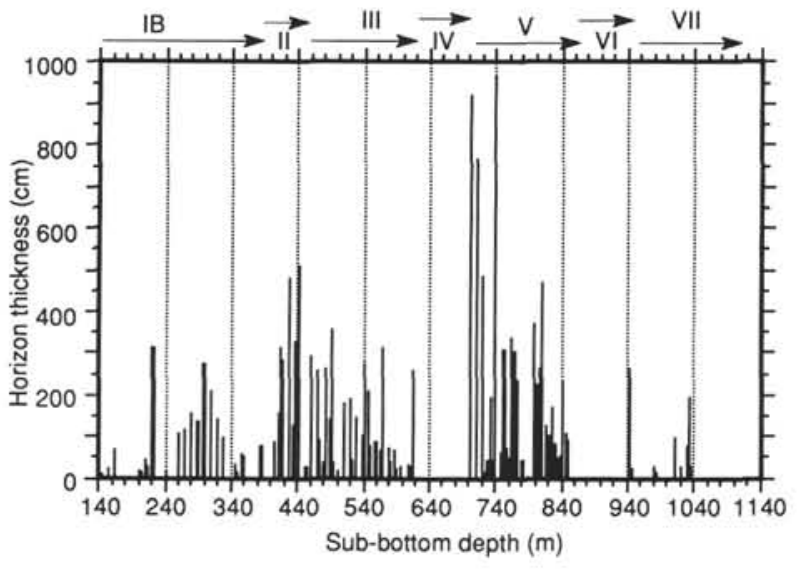

c

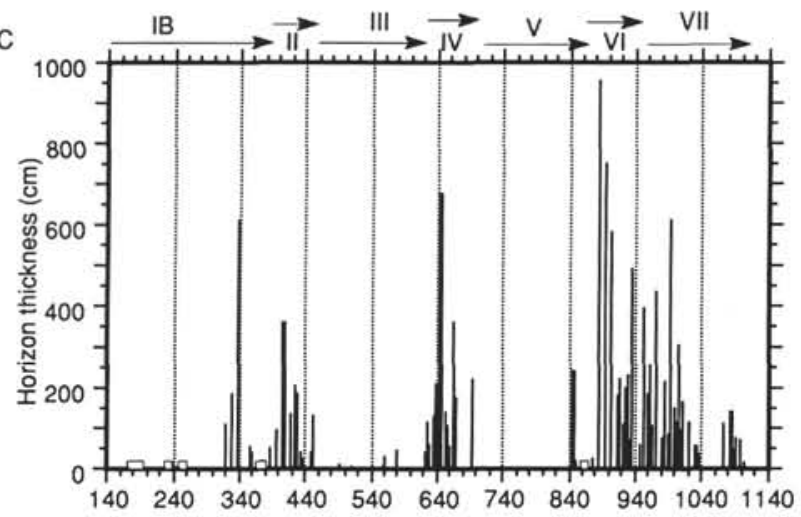

D

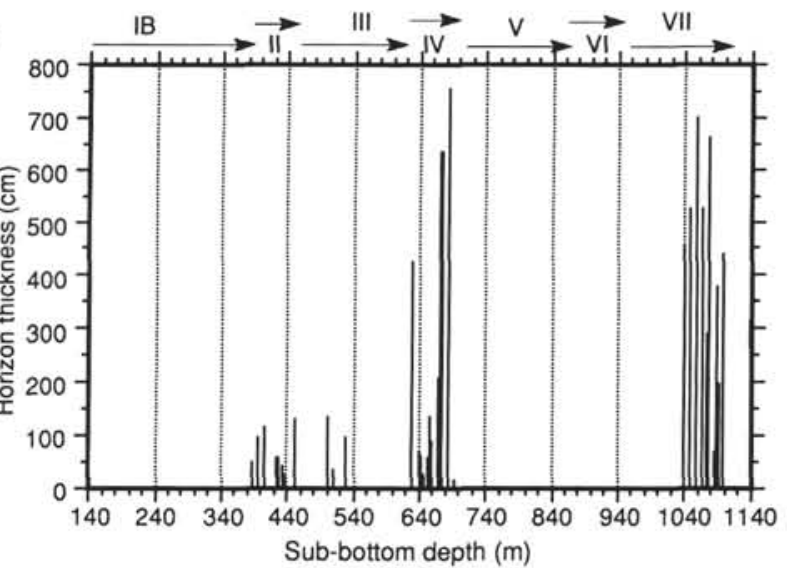

Figure 6. Depth vs. thickness relationships for sediment horizons recovered from Hole 832B. A. Ash horizons. B. Hemipelagic horizons. C. Turbidite horizons. D. Debris-flow horizons. Intervals of nonrecovery $>10 \mathrm{~m}$ are indicated by boxes on the $x$-axis. Plotted depth indicates the top of the layer. Note differences in scales on the vertical axes.

Units II and III, from 385 to $626 \mathrm{mbsf}$, are composed of interbedded debris flows, turbidites, and hemipelagic sediments, with very few ash layers. Beds have thicknesses up to, and occasionally exceeding, $3 \mathrm{~m}$ (Fig. 6). The hemipelagic sediments and debris-flow matrix become gradually more calcareous with depth in Unit II, and the fine sediment of the hemipelagic and turbidite beds is as much as $50 \%$ calcium carbonate (Fig. 8). Turbidites display laminations, slump structures, and microfaults. The debris flows contain rounded-to-angular clasts, from 1 to $40 \mathrm{~cm}$ in diameter, of basalt, chalk, neritic carbonates, and siltstone, in a sandy matrix of epiclastic and calcareous material. Glass is rare in the sediments but unaltered in some basalt clasts; other clasts appear weathered. Most basalt clasts include phenocrysts of clinopyroxene and plagioclase, which is compositionally consistent with an origin on Maewo or Aoba, but not on Santa Maria or Espiritu Santo; however, one clast from $551.7 \mathrm{mbsf}(134-832 \mathrm{~B}-43 \mathrm{R}-3,23-26 \mathrm{~cm})$ is a hornblende-bearing basaltic andesite that most likely came from Espiritu Santo (Shipboard Scientific Party, 1992a; Macfarlane et al., 1988). The mixture of clast types, the high calcium carbonate content, and the large clast size suggest that these units resulted from rapid subaerial erosion related to tectonic uplift. The mixture of clasts also suggests multiple sources.

At the top of Unit IV, which extends from 626 to $702 \mathrm{mbsf}$, fine-grained calcareous input ends abruptly, and the cores consist of thick-bedded volcaniclastic gravity flow deposits, alternating between debris flows, sandstones, and occasional fine-grained turbidites featuring laminations and contorted and microfaulted beds (Fig. 6). Clasts of shallow water limestone and corals are found in some of the upper debris-flow deposits, and deeper in the section one depositional unit extends $22 \mathrm{~m}$, from 670 to $692 \mathrm{mbsf}$, and features a single basaltic clast with a diameter of $70 \mathrm{~cm}$. Basalt clasts in this unit are similar to those in Units II and III, and although glass is rare, palagonite is abundant at some horizons, suggesting alteration before deposition, or submarine volcanism (Fisher and Schmincke, 1984).

The lithology changes suddenly at the top of Unit V, from the volcaniclastic gravity flow deposits of Unit IV to $164 \mathrm{~m}$ of hemipelagic, calcium carbonate-rich siltstone and claystone (Figs. 6 and 8), similar in its variability to Subunit IB. Trace fossils are ubiquitous, and thin, devitrified ash layers (1-20 cm thick), partially or thoroughly bioturbated, are scattered throughout the core. Between 740 and $770 \mathrm{mbsf}$, scaly fabric (faulted surfaces displaying slickensides) and sets of branching vein structures are common. These indicators of structural deformation were interpreted by Lundberg and Moore (1986) as being caused by extensional strain.

The lowermost $20 \mathrm{~m}$ of Unit V includes a 140-cm-thick volcanic sandstone and a 250 -cm-thick, grain-flow deposit containing rounded clasts of neritic carbonates and displaying slump features. This serves as a transition to Unit VI, an 86-m-thick section of thick, finingupward sequences of sandy volcaniclastic turbidites (Fig. 6). A general coarsening downward occurs over Unit VI, grading into the basaltic debris flows, turbidites, and scarce hemipelagic beds of Unit VII, which begins at 952 mbsf. Clasts of neritic carbonate are found in the debris-flow deposits down to a depth of $1037 \mathrm{mbsf}$, indicating a shallow-water origin for the flows. Pumice clasts are also common, dominating the clasts in one interval of conglomerate. Below 1037 mbsf, to the bottom of the core at 1107 mbsf, matrix and clasts are all volcanic. The basalt clasts differ in composition from those in overlying units, featuring fresh orthopyroxene phenocrysts in addition to clinopyroxene, plagioclase, and olivine, making Espiritu Santo and Maewo islands the most likely sources (Shipboard Scientific Party, 1992a; Macfarlane et al, 1988). The basalt clasts are, in some cases, 
altered only slightly, though the sand-silt matrix in the bottom $55 \mathrm{~m}$ is rich in volcanic alteration products such as palagonite, chlorite, and zeolite, suggesting submarine volcanism in that interval (Shipboard Scientific Party, 1992a; Fisher and Schmincke, 1984).

\section{Site 833 Sedimentary Record}

The uppermost $40 \mathrm{~m}$ of Hole $833 \mathrm{~A}$ (Subunit IA) consists of interbedded hemipelagic sediments and ashfall deposits (Fig. 9). The proportion of ash increases with depth; beginning at $10.5 \mathrm{mbsf}$, many ash horizons, 5-120 cm thick, consist of banded, 1- to 4-cm-thick, finingupward sequences. Gravity-driven sedimentation processes are evidenced by scattered occurrences of poorly consolidated layers of volcanic silts with clasts of siltstone gravel, and by slumps and contorted beds within some banded ashes. At $40 \mathrm{mbsf}$, the coherent silt and ash interbeds of Subunit IA are supplanted by watery layers of vitric ash, as much as $4.7 \mathrm{~m}$ thick, interbedded with massive volcanogenic siltstone beds which make up the $45 \mathrm{~m}$ of Subunit IB (Fig. 9). Gravel-sized clasts of clayey siltstone are scattered throughout Subunit IB, concentrated into a lumpy, $80-\mathrm{cm}$ conglomerate horizon at $76 \mathrm{mbsf}$. The thick ash deposits were certainly deposited by turbidity currents, contemporaneous with or shortly following volcanic eruptions. Like those in Hole $832 \mathrm{~A}$, they reflect the episodic volcanic history of the Central Chain volcanoes.

Unit II begins abruptly at $85 \mathrm{mbsf}$ in Hole $833 \mathrm{~A}$ and at $77 \mathrm{mbsf}$ where recovery begins in Hole $833 \mathrm{~B}$, with a change in sediment character from watery ash to well-lithified, fine-grained hemipelagics with a significant calcareous component (Figs. 9 and 10). Sediment layers are generally on a scale of a centimeter to tens of centimeters in thickness, and they vary in structure and composition: some are laminated, some massive; many display abundant trace fossils; some have high concentrations of foraminifers, nannofossils, and/or fine-grained calcium carbonate sediment of indeterminate origin (Fig. 8). Ash horizons are rare in the upper and lower-middle reaches of the unit (Subunits IIA and IIC) but they are common, though altered, in the other two subunits (Fig. 10). Subunit IIC is a particularly calcareous unit, and within it the interval from 273 to 308 mbsf appears to be a series of grain and debris flows, featuring scattered neritic carbonate cobbles (including $40 \mathrm{~cm}$ of cobbles of mollusk algal floatstone) and folded and contorted beds and laminations. The heterogeneous sediment character of the beds in Unit II, both within and between subunits, suggests variation in the sediment sources and depositional processes.

Subaerial erosion and downslope processes dominate sedimentation once again at 376 mbsf with the beginning of Unit III, which consists of $200 \mathrm{~m}$ of volcaniclastic sandstones and breccias laid down by turbidites and debris flows; silty hemipelagic interbeds are rare (Fig. 10). Each gravity flow sequence generally comprises a coarse basaltic debris flow fining upward into a sandy turbidite; thicknesses range from about 0.5 to over $7 \mathrm{~m}$. Debris-flow deposits from 490 to $505 \mathrm{mbsf}$ contain cobbles (or boulders) of calcareous claystone and volcanic siltstone as well as basalt, probably reflecting subaerial erosion and mixing in shallow water. Volcanic glass is rare in the sediments, but zeolites and chlorite are common, and most of the basalt clasts appear oxidized or otherwise altered, suggesting epiclastic origins for the unit.

Below 578 mbsf, in Unit IV, debris-flow deposits occur only rarely, volcanic sandstone turbidites become thinner and less frequent, devitrified (zeolitic) ash layers appear, and calcareous hemipelagic horizons, bioturbated and showing abundant trace fossils, become the dominant sediment type (Figs. 8 and 10). Bed character is similar to Unit II; composition is heterogeneous and layers are generally similar in thickness, averaging 36.8 vs. $37.9 \mathrm{~cm}$ in Unit II, though the median thickness of $20 \mathrm{~cm}$ is slightly higher than the $16 \mathrm{~cm}$ median of Unit II. Laminations, frequently caused by foraminiferal content, are common, and highlight the apparent dip (usually $<8^{\circ}$, but ranging up to $60^{\circ}$ ) to many of the beds. Only a few sediment structures resulted from the gravity-driven flows: fining-upward sequences and occa-

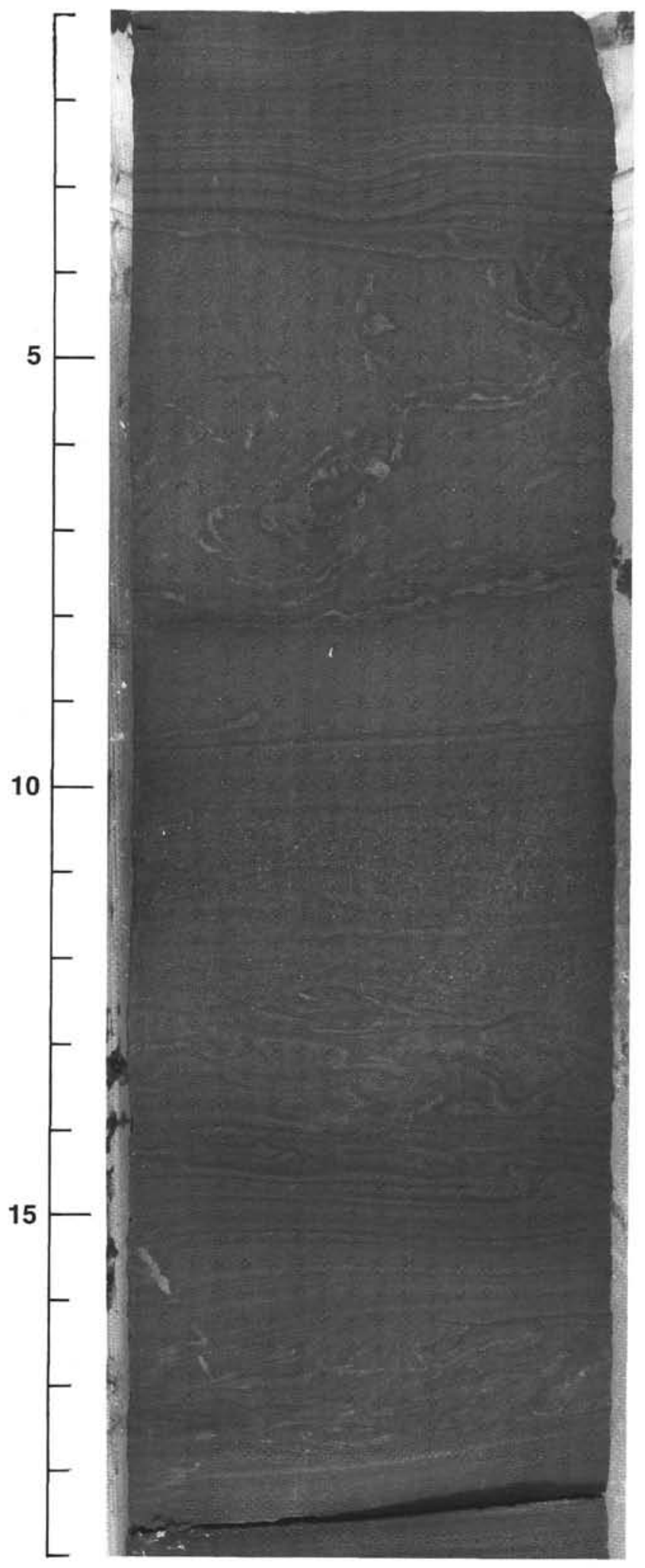

Figure 7. Laminations, flow structures, and deformation displayed in silty basinal turbidites of Subunit IB, 341.9 mbsf (sample 134-832B-21R-4, 1-19 $\mathrm{cm})$. 

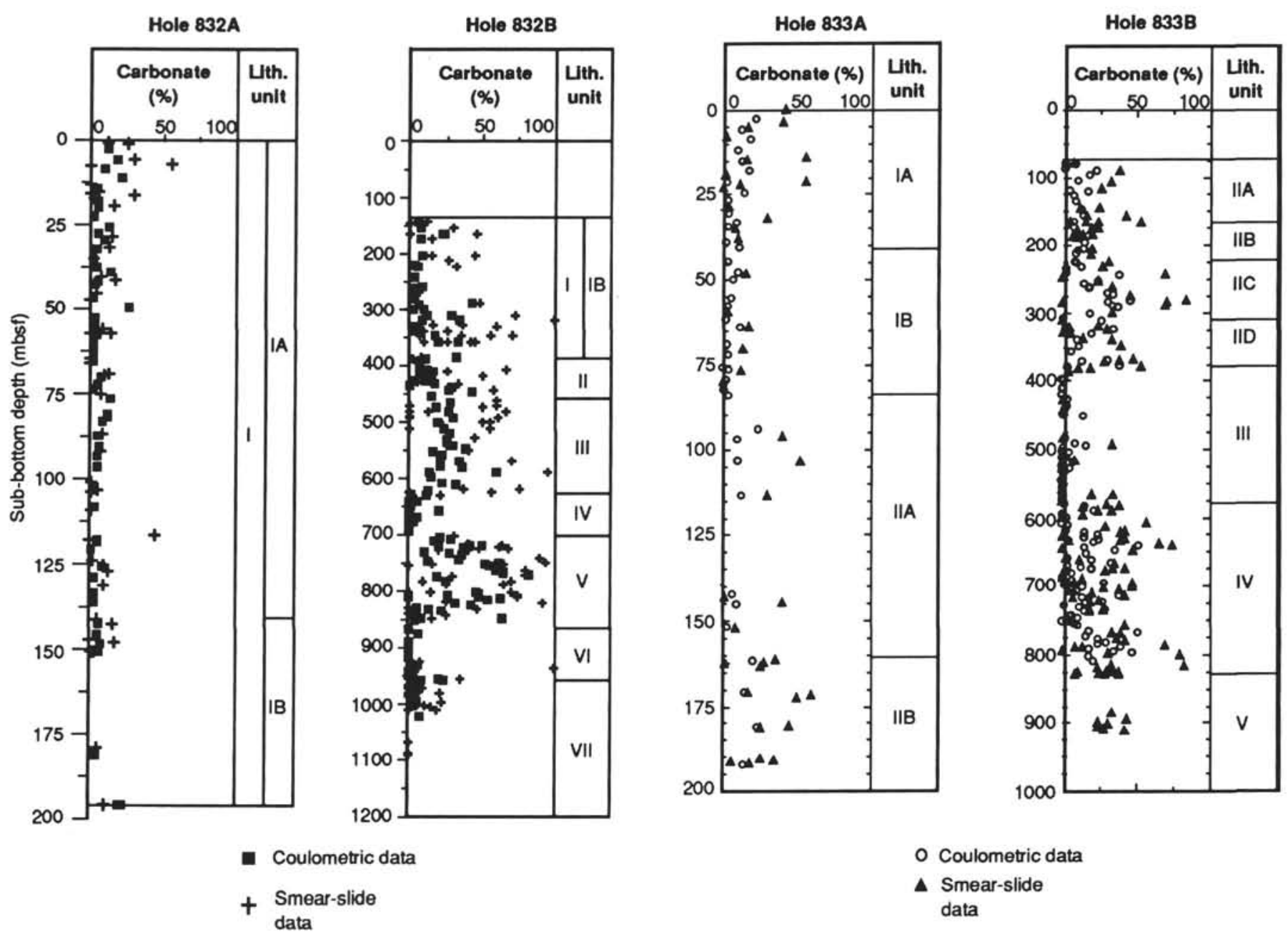

Figure 8. Calcium carbonate content of sediments from Holes 832A, 832B, 833A, and 833B, observed and measured on board Leg 134 (from Shipboard Scientific Party, 1992a, 1992b).

sional cross laminations in the turbidites, and a calcareous debris flow with contorted beds and siltstone cobbles at 771.65 mbsf. Heterogeneous, hemipelagic-dominated sediments similar to those in Unit IV have been intruded by a basalt sill in Unit V (Fig. 2).

\section{SEDIMENTATION HISTORY}

The thick, varied sediments recovered from the North Aoba Basin testify to periods of volcanic activity and tectonic uplift, with intervening quiescent periods marked by slower erosion, and in some instances subsidence, of the surrounding islands. The active periods left thick, coarse-grained, fining-upward sequences, indicating rapid downslope transport. Between those turbulent times, the record consists primarily of hemipelagic sediments and thin, silty turbidites, reflecting slower erosion rates and volcanic quiescence. By combining the sedimentologic information with paleontological and radiometric ages from the North Aoba Basin cores, and comparing that with the geologic history of the New Hebrides Island Arc, I am able to generate a basin sedimentation history.

\section{Miocene Sedimentation}

The oldest sediments in the cores come from Units VI and VII at the bottom of Hole 832B. The age of the sediments there is questionable because dates based on paleontological data are inconsistent with geochemical dating. Fossils used for dating are rare in the volcani- clastic debris-flow deposits, turbidites, and even hemipelagic sediments below 856 mbsf (Units VI and VII). In Unit VII, sparse foraminiferal data, found only at 1008.6 and 972 mbsf, gave an age of early middle Miocene (14-15 Ma; Perembo, this volume), and nannofossil data are consistent with an age of middle Miocene for the sediments at a depth of 972-1037 mbsf (12-14 Ma; Staerker, this volume). However, a basalt clast at a depth of 1101.5 mbsf was dated, using $\mathrm{K} / \mathrm{Ar}$ analysis, at $5.66 \mathrm{Ma}$ (Rex, this volume), placing its origin in the latest Miocene (Fig. 2). The overlying sequences of ashfalls and turbidites making up Unit VI are dated late Miocene.

If the geochemical date is incorrect, then a major unconformity separates Units VI and VII, representing the period from approximately 14 to $6 \mathrm{Ma}$. Alternatively, if the $\mathrm{K} / \mathrm{Ar}$ date is correct, then the older fossils must have been uplifted, eroded, and re-deposited at their present location.

I find the latter interpretation most convincing for the following reasons:

1. The fossils are located in sediments emplaced by debris flows originating in shallow water.

2. Espiritu Santo Island displays sediments of the same type and age as the sediments displayed in Units VII and VI of Hole 832B, and it was undergoing uplift and erosion from 11 to $7.5 \mathrm{Ma}$, a period not represented in the cores (Fig. 3; Mitchell and Warden, 1971; Carney et al., 1985; Macfarlane et al., 1988). Espiritu Santo might logically, therefore, serve as a source for the older fossils. 
3. Maewo Island was volcanically active in the late Miocene, consistent with the $\mathrm{K}-\mathrm{Ar}$ date, and could have served as a source for much of the volcaniclastic debris-flow and turbidity-current deposits (Fig. 3; Mitchell and Warden, 1971; Carney et al., 1985; Macfarlane et al., 1988).

4. Unit VII basalts display orthopyroxene phenocrysts, as do lava clasts on Maewo and Espiritu Santo (Shipboard Scientific Party, 1992a; Carney, 1986), so either is a consistent source for the volcanic clasts in the deepest breccias.

\section{Late Miocene to Pliocene}

The volcanogenic component in Hole 832B gradually fades in importance in the finer grained upper Miocene sediments of Unit V that begin at $856 \mathrm{mbsf}$. The last thick, sandy volcaniclastic turbidite ends at $836.7 \mathrm{mbsf}$, and ashflow deposits are infrequent by $827 \mathrm{mbsf}$, although 1-20-cm-thick layers of altered tephra throughout Unit V (702-856 mbsf) record continued explosive volcanism throughout the Pliocene (Fig. 6). The calcareous, bioturbated hemipelagics predominant in Unit V, though similar in lithology, are cut by an unconformity at 772 mbsf: late Miocene to earliest Pliocene sediments are unconformably overlain by $24 \mathrm{~m}$ ( $748-772 \mathrm{mbsf}$ ) of sediment from the late early Pliocene, which grades into $48 \mathrm{~m}$ of late Pliocene hemipelagics (700-748 mbsf; Figs. 2 and 3; Staerker, this volume). The $24 \mathrm{~m}$ of sediments immediately above the unconformity feature a concentration of vein structures and normal faults displaying slickensides, none of which are found in the overlying beds, but which do occur in smaller numbers in the underlying hemipelagic beds.

The hemipelagic sediments of Unit V in Hole 832B correspond in age to the continuous lower to upper Pliocene hemipelagic and gravity flow deposits of Units IV and V in Hole 833B. The oldest sediments in Hole 833B are lower Pliocene, extending from 953 up to $664 \mathrm{mbsf}$ near the top of Unit IV, and intruded by $100 \mathrm{~m}$ of basaltic sills dated at 3.3-3.8 Ma (Rex, this volume). This sequence is overlain by $82 \mathrm{~m}$ of upper Pliocene material of similar origin. This $371 \mathrm{~m}$ sequence corresponds in age to the $72 \mathrm{~m}$ sequence in Hole $832 \mathrm{~B}$ that is bounded by unconformities (Fig. 2). However, these contemporaneous deep-water facies have distinct differences in character (Figs. 2 and 3). Instead of a homogeneous, bioturbated, calcareous hemipelagic unit broken infrequently by horizontally bedded, smeared ashfalls, the lower Pliocene sediments in Hole 833B are heterogeneous interbeds of volcaniclastic and calcareous turbidites, hemipelagics, ashfalls, and debris flows, with bedding angles up to $60^{\circ}$, and sedimentary structures including slumped and contorted beds, parallel and wavy laminae, microfaults, and trace fossils. Calcareous hemipelagic beds similar to those in Hole 832B are found as interbeds in the lower Pliocene sediments of Hole 833B, but sedimentation is dominated by gravity-flow deposition, probably associated with the continuing uplift of Maewo (Carney et al., 1985). Volcanism in the Pliocene record is represented in both holes by ashfalls that may or may not have originated on Maewo, as volcanism is conjectured to have ceased there by early Pliocene time (Fig. 3). The unconformities at Site 832 may have been caused by local uplift associated with the resumption of uplift of the Western Belt, or the uplift of Maewo and Espiritu Santo may have formed basins that blocked the sediment supply to the central basin.

\section{Late Pliocene to Pleistocene}

In the upper Pliocene-lower Pleistocene sequences, volcanogenic sediments become prominent in both holes (Fig. 2). In both, the volcanic sediment content begins gradually near the top of the underlying hemipelagic units (Unit V at Site 832 and Unit IV at Site 833) and grade upward into volcanic sandstones, which themselves grade up into sedimentary breccias with clasts of basalt and siltstone (Fig. 2). The sedimentological character of Sites 832 and 833 diverge after the start of the Pleistocene. In Unit II of Hole 833B, hemipelagic sedimentation increases and turbidite frequency decreases (Fig. 10), signaling a slow-
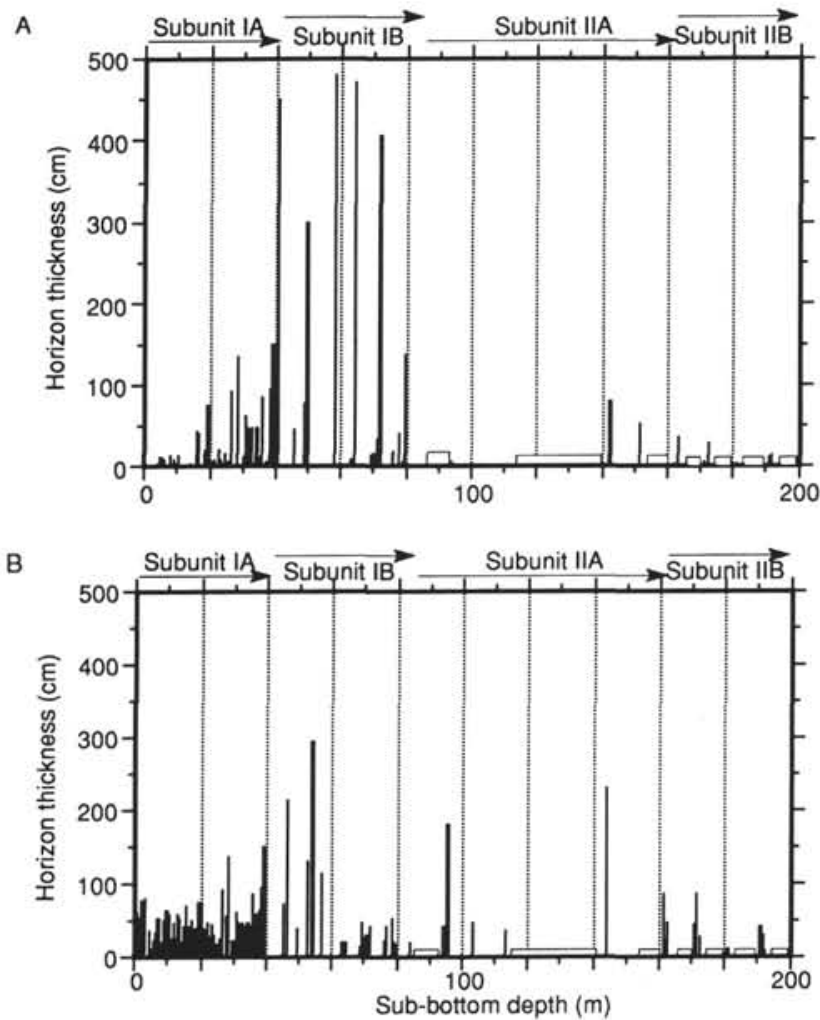

Figure 9. Depth vs. thickness relationships for sediment horizons in Hole 833A. A. Ash horizons. B. Hemipelagic horizons. Intervals of nonrecovery $>4 \mathrm{~m}$ are indicated by boxes on the $x$-axis. Plotted depth indicates the top of the layer.

ing of uplift in the Eastern Belt. By contrast, in the upper reaches of Unit IV in Hole 832B, above 635 mbsf, neritic clasts are mixed with the basaltic clasts in breccia units, which grade into the calciumcarbonate-rich, interbedded debris-flow deposits, turbidites, and hemipelagics of Unit III and the volcaniclastic interbeds of debris flows, turbidites, and hemipelagics of Unit II (Fig. 2). These units are of early Pleistocene age, coeval with Subunits IIB, IIC, and IID of Hole 833 (Figs. 2 and 3; Shipboard Scientific Party, 1992a).

The volcanic clasts in the upper Pliocene units are mostly pyroxene-phyric basalts (ankaramites), which is consistent with observations of volcanic rocks on either Maewo or Aoba (Shipboard Scientific Party, 1992b; Macfarlane et al., 1988). The weathered nature of the clasts from Hole 833 suggests that these flows originated from subaerial erosion brought about by the continued uplift of Maewo in the late Pliocene. However, many of the lava clasts in Hole 832B appear relatively fresh, and one was dated at $2.8 \pm 0.8 \mathrm{Ma}$ (Rex, this volume). This date is older than the known Central Chain volcanism in the Aoba Basin area, but it is younger than the projected end of volcanism on Maewo (Macfarlane et al., 1988).

Despite some similarities, the upper Pliocene debris flows of Sites 832 and 833 are probably different in origin. The debris flows on the eastern margin of the basin in Hole 833B appear to result directly from uplift and weathering on Maewo, whereas the volcanic breccias at the base of Unit IV in Hole 832B probably result from submarine volcanism early in the history of Aoba or Santa Maria. The appearance of neritic carbonates in those breccias at 632 mbsf may signal that the volcanic source emerged above sea level. Instead (or in addition), it might signify the beginning of sediment mixing from a newly emergent Espiritu Santo Island with the younger Central Chain volcanic sediments. The sills between Espiritu Santo and Aoba Islands and Maewo and Aoba Islands are likely locations for such mixing, and canyons appear to lead down from those saddles into the North and 

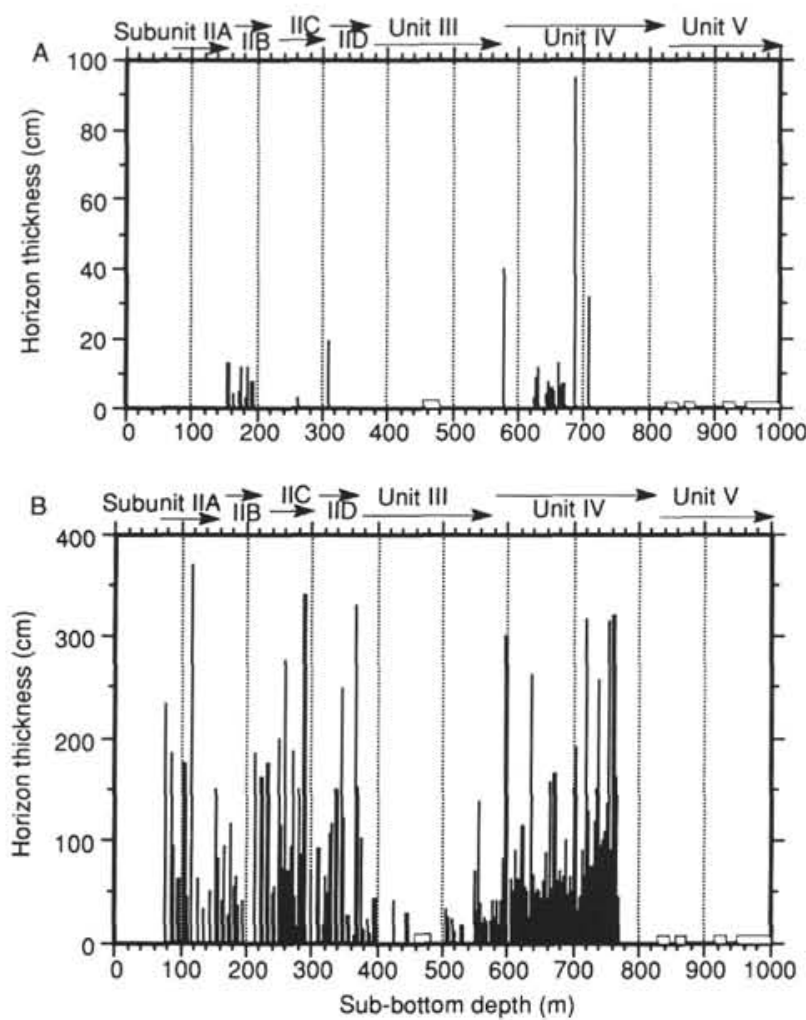
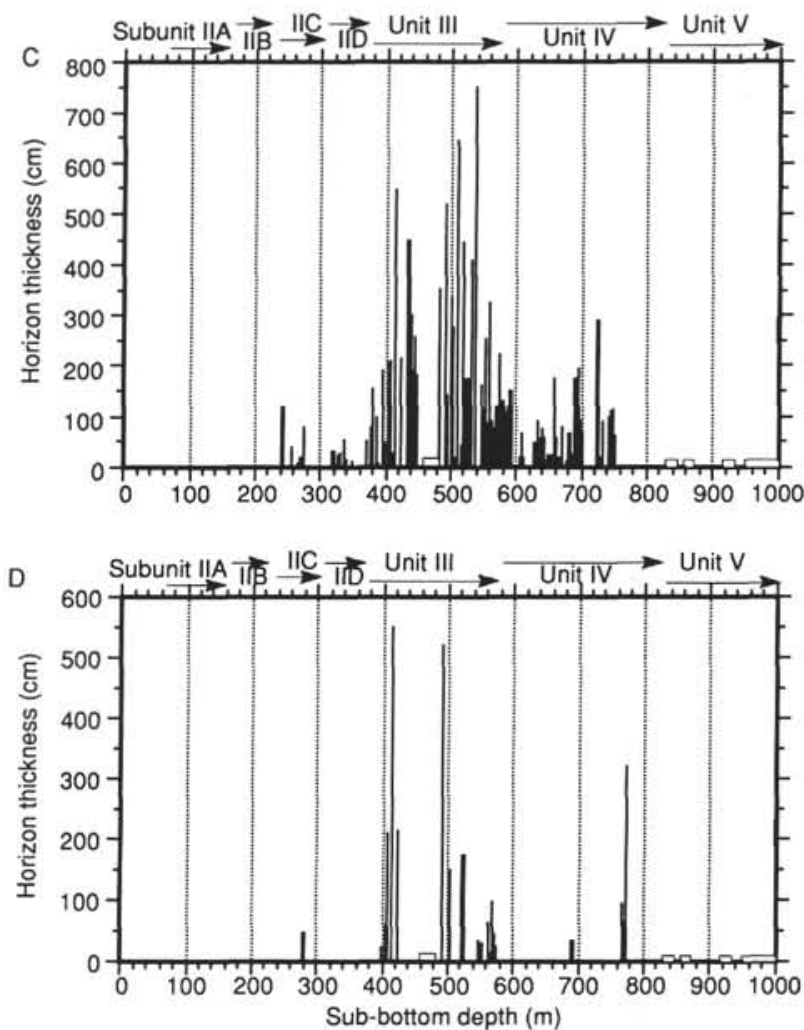

Figure 10. Depth vs, thickness relationships for sediment horizons recovered from Hole $833 \mathrm{~B}$. A. Ash horizons, B. Hemipelagic horizons. C. Turbidite horizons. D. Debris-flow horizons. Intervals in which only intrusive sill rocks were recovered, and the single interval of nonrecovery $>10 \mathrm{~m}$ (at $460 \mathrm{mbsf}$ ), are indicated by boxes on the $x$-axis. Plotted depth indicates the top of the layer. Note differences in scales on the vertical axes.

South Aoba Basins (Fig. 1). The occurrence in the middle of Unit III in Hole 832, noted above, of a volcanic clast that probably originated on Espiritu Santo Island, combined with the heterogeneous, calcareous nature of the deposits from both sites, lend strength to this argument. Increased volcanic input is reflected in the altered tephra layers and volcanic sands in Unit II in Hole 832 and Subunit IIB in Hole 833.

\section{Late Pleistocene to Holocene}

A period of hemipelagic sedimentation in the late Pleistocene is represented at Site 832 by Subunit IB and at 833 by Subunit IIA (Fig. 2 ). Both display turbidite and ashfall horizons, but they are much thicker, coarser grained, and more frequent at Site 832, where the 30 $\mathrm{m}$ of Subunit IB recovered from Hole $832 \mathrm{~A}$ is entirely fine-grained vitric ash. The sediments are more calcareous at Site 833. These lithologic differences reflect continuing input to Site 833 from Maewo as it was uplifted, and increasing input to Site 832 from Aoba and Santa Maria Islands as they emerged.

Each site also underwent a phase in the late Pleistocene when sedimentation was dominated by thick, watery ashflow deposits, though these horizons are much thicker in Hole 832A (123 m, making up most of Subunit IA) than in Hole 833A (43.2 m, all of Subunit IB). The overlying sediments are interbedded hemipelagics, tephra layers, and thin ash turbidites. The sequences demonstrate the accumulation of volcaniclastic aprons during very active and intermittent periods of volcanism, and highlight the difference between a basin floor vs. basin margin location.

\section{CONCLUSIONS}

The sediments recovered from drilling the North Aoba Basin offer new constraints on the volcanic and tectonic history of the central
New Hebrides Island Arc. From the late Miocene through most of the Pliocene, sedimentation was dominated by events on Maewo: first its volcanism, then its erosion and subsequent uplift, though Espiritu Santo was also a source of some sediment. By the late Pliocene, the uplift of Espiritu Santo and volcanism developing in the Central Chain offered new sources of sediment, and the sedimentation patterns became more complex. Since the late Pleistocene, Central Chain volcanism has overwhelmed sediment contributions from other sources.

Sedimentation processes reflect the tectonic processes. During times of uplift and/or volcanism, the availability of abundant sediments, including boulders and gravels, caused debris flows that resulted in the sedimentary breccias found intermittently throughout the North Aoba Basin cores. Slower erosion and intermittent subaerial eruptions led to silty turbidites, hemipelagic sediments, and tephra fall layers. Periods of intense explosive eruptions led to the recent buildup of volcaniclastic aprons through ashflow deposits.

\section{REFERENCES ${ }^{*}$}

Berggren, W.A., 1985. Cenozoic geochronology. Geol. Soc. Am. Bull., 96:14071418.

Carey, S., and Sigurdsson, H., 1984. A model of volcanogenic sedimentation in marginal basins. In Kokelaar, B.P., and Howells, M.F. (Eds.), Marginal Basin Geology: Volcanic and Associated Sedimentary and Tectonic Processes in Modern and Ancient Marginal Basins: Geol. Soc. Spec. Publ. London, 16:37-58.

Carney, J.N., 1986. Geology of Maewo. Region. Rep.-Vanuatu Dep. Geol., Mines and Rural Water Suppl.

\footnotetext{
Abbreviations for names of organizations and publications in ODP reference lists follow the style given in Chemical Abstracts Service Source Index (published by American Chemical Society).
} 
Carney, J.N., and Macfarlane, A., 1982. Geological evidence bearing on the Miocene to Recent structural evolution of the New Hebrides Arc. Tectonophysics, 87:147-175.

Carney, J.N., Macfarlane, A., and Mallick, D.I.J., 1985. The Vanuatu island arc: an outline of the stratigraphy, structure, and petrology. In Nairn, A.E.M., Stehli, F.G., and Uyeda, S. (Eds.), The Ocean Basins and Margins (Vol. 7): New York (Plenum), 685-718.

Collot, J.-Y., Greene, H.G., Stokking, L.B., et al., 1992. Proc. ODP, Init. Repts., 134: College Station, TX (Ocean Drilling Program).

Daniel, J., 1978. Morphology and structure of the southern part of the New Hebrides island arc system. J. Phys. Earth, 26:S181-S190.

Fisher, R.V., 1984. Submarine volcaniclastic rocks. In Kokelaar, B.P., and Howells, M.F. (Eds.), Marginal Basin Geology: Volcanic and Associated Sedimentary Processes in Modern and Ancient Basins. Geol. Soc. Spec. Publ. London, 16:5-28.

Fisher, R.V., and Schmincke, H.-U., 1984. Pyroclastic Rocks: New York (Springer-Verlag).

Huang, T.C., 1980. A volcanic sedimentation model: implications of processes and responses of deep-sea ashes. Mar. Geol., 38:103-122.

Klein, G.deV., 1985. The control of depositional depth, tectonic uplift, and volcanism on sedimentation processes in the back-arc basins of the Western Pacific Ocean. J. Geol., 93:1-25.

Klein, G.deV., and Lee, Y., 1984. A preliminary assessment of geodynamic controls on depositional systems and sandstone diagenesis in back-arc basins, western Pacific Ocean. Tectonophysics, 102:119-52.

Kroenke, L., Scott, R., et al., 1981. Init. Repts. DSDP, 59: Washington (U.S Govt. Printing Office).

Lundberg, N., and Moore, J.C., 1986. Macroscopic structural features in Deep Sea Drilling Project cores from forearc regions. In Moore, J.C. (Ed.), Structural Fabric in Deep Sea Drilling Project Cores From Forearcs Mem.-Geol. Soc. Am., 166:13-44.

Macfarlane, A., Carney, J.N., Crawford, A.J., and Greene, H.G., 1988. Vanuatu-a review of the onshore geology. In Greene, H.G., and Wong, F.L.
(Eds.), Geology and Offshore Resources of Pacific Island Arcs-Vanuatu Region. Circum-Pac. Counc. Energy Miner. Resour., Earth Sci. Ser., 8:45-91. Mallick, D.I.J., 1973. Some petrological and structural variations in the New Hebrides. In Coleman, P.J. (Ed.), The Western Pacific: Island Arcs, Marginal Seas, Geochemistry: Nedlands (Univ. of W. Austr. Press), 193-211.

Middleton, G.V., and Hampton, M.A., 1973. Sediment gravity flows: mechanics of flow and deposition. In Middleton, G.V., and Bouma, A.H. (Eds.), Turbidites and Deep Water Sedimentation. Short Course Notes, Soc. Econ. Paleontol. Mineral., Pacific. Sect., 1-38.

Mitchell, A.H.G., and Reading, H.G., 1986. Sedimentation and tectonics. In Reading, H.G. (Ed.), Sedimentary Environments and Facies: Oxford (Blackwell), 471-519.

Mitchell, A.H.G., and Warden, A.J., 1971. Geological evolution of the New Hebrides island arc. J. Geol. Soc, London, 127:501-529.

Shipboard Scientific Party, 1992a. Site 832. In Collot, J.-Y., Greene, H.G., Stokking, L.B., et al., Proc. ODP, Init. Repts., 134: College Station, TX (Ocean Drilling Program), 387-477.

1992b. Site 833. In Collot, J.-Y., Greene, H.G., Stokking, L.B., et al., Proc. ODP, Init. Repts., 134: College Station, TX (Ocean Drilling Program), 479-557.

Sparks, R.S.J., and Walker, G.P.L., 1977. The significance of vitric enriched air-fall ashes associated with crystal-enriched ignimbrites. J. Volcanol. Geotherm. Res., 2:329-341.

Taylor, F.W., 1992. Quaternary vertical tectonics of the central New Hebrides Island Arc. In Collot, J.-Y., Greene, H.G., Stokking, L.B., et al., Proc. ODP, Init. Repts., 134: College Station, TX (Ocean Drilling Program), 33-42.

Date of initial receipt: 28 May 1992

Date of acceptance: 5 November 1993

Ms 134SR-007 